\title{
Primary production and seasonal dynamics of the flora and fauna of the field stratum in a reserved field in Middle Finland
}

\author{
Timo TörmäLÄ and Mikкo RaAtikainen \\ University of Jyväskylä, Department of Biology \\ Vapaudenkatu 4, 40100 \\ Jyväskylä 10, Finland
}

\begin{abstract}
The underground biomass of a reserved field which had not been cultivated for three years, exceeded that of the aboveground living vegetation throughout the year. The mean amount of the aboveground detritus, including both loose litter and rooted nonliving parts of the vegetation, was in dry weight $300 \mathrm{~g} / \mathrm{m}^{2}$. It was at its minimum end of June and early July. The aboveground net primary production measured by the harvesting method was $405-415 \mathrm{~g} / \mathrm{m}^{2}$. year depending on the way of calculation, and the underground production was $343 \mathrm{~g} / \mathrm{m}^{2}$. year.

Seasonal dynamics of the green biomasses of 56 taxa could be studied and five groups were formed on the basis of the time and duration of the biomass maxima. Using Renkonen's and Sørensen's indices three seasonal aspects of the vegetation could be distinguished.

The leafhoppers were divided into three phenological groups, and three seasonal aspects were formed. The vertebrate fauna was scarce in the study area. Shrews were the most abundant species and e.g. five Sorex isodon were trapped.

During the period of maximum standing crops the herbivores amounted to $0.3 \%$ of the green biomass. The higher the trophic level the later it reached the maximum.
\end{abstract}

\section{Introduction}

In the 1960 's the authorities concluded that there was an excess of cultivated area in Finland. In April 1969 a law of restrictions on the use of cultivated fields was enacted. Subsidies were to be paid to farmers who ceased cultivating their fields, with the contract to be valid at the most for 15 years. The last contracts could be signed on 1 May 1974.

The total cultivated area in Finland was 2.6 million hectares in 1975. Contracts of field reservation amounted on 31 December 1975 to 27833 . The total area of reserved fields was 182211 ha and the area of forested fields was 22056 ha. Several reports have been published about the field reservation activities (e.g. JAATINEN and KÄRKKÄINEN 1970, 1971, JAATINEN and NYGÅRD 1972, 1973). 
According to the regulations, the farmer has to take care of the reserved field so that it is not colonized by weeds to such an extent that it is harmful to surrounding cultivations. Consequently, shoots have been cut and several reserved fields have been mowed or even ploughed.

Research on the flora and fauna of reserved fields was started in the University of Jyväskylä in 1973. This is the first publication on this subject. Comparable grassland studies have earlier been made for exaple in the USA (Golley 1960, 1965, Wiegert and Evans 1964) and in Poland (Traczy K 1968, Ekologia Polska 19). A meadow in South Finland has also been studied thoroughly (Gyllenberg 1969, Kosonen 1969) and a large regional study on the fauna and flora of the leys is in progress (e.g. Huhta and RaAtikainen 1974, RaAtikainen and RaAtikainen 1975).

\section{Study area}

The field studied is located in the rural commune of Jyväskylä alongside the lake Ruokepuolinen ( $\mathrm{N} 62^{\circ} 14^{\prime}$, E $\left.25^{\circ} 36^{\prime}\right)$. The 6 ha field is flanked by the lake and by spruce forest. The actual study area consisted of six strips, which had last been on oat (Figs. 1 and 2). The strips had been cultivated for some 50 years. Contract on the field reservation was signed in 1969, thus the strips had been uncultivated for four growing seasons before the study. They had not been managed in any way during that time. The area of the six strips was in total $0.66 \mathrm{ha}$. The strips slope towards the lake $3.6 \mathrm{~m} / 100 \mathrm{~m}$. The study area had open ditches. The soil was fine sand. The summer of 1973 was on an average warmer than normal excluding August and September, and the rainfall was greater than normal except for a dry July.

\section{Methods}

\subsection{Aboveground vegetation}

The net primary production was measured by harvesting method mainly according to the instructions given by Milner and Hughes (1968). From the six strips twenty sampling sites, with as uniform a vegetation as possible, were selected. The southwestern corners of the 5 times 10 meter sampling sites were used as origo when deciding by paired random figures the actual clip-plots. Vegetation samples were clipped from each sampling site on 29. IV, 21. V, 14. VI, 30. VI, 21. VII, 13. VIII, 4. IX and 26. IX. 1973. Comparison samples were taken on 9 . V. 1974. The clip-plots were limited by a $0.25 \mathrm{~m}^{2}$ metal circle. Clip-plots of the same size have been used e.g. by Golley (1960, 1965 ) in abandoned fields, by GYLLENBERG (1969) in coastal meadows, and by RaAtikainen and RaAtikainen $(1975)$ in hay fields. Traczyk $(1968,1971)$ used mainly clip-plots of $0.1 \mathrm{~m}^{2}$.

When sampling the aboveground vegetation the metal circle was placed on the ground and the loose detritus was first removed into plastic bags. Then the vegetation was clipped at ground level with small garden scissors. The clipping was always done by the same person. 
Fig. 1. Study area.

Foto Timo Törmälä.
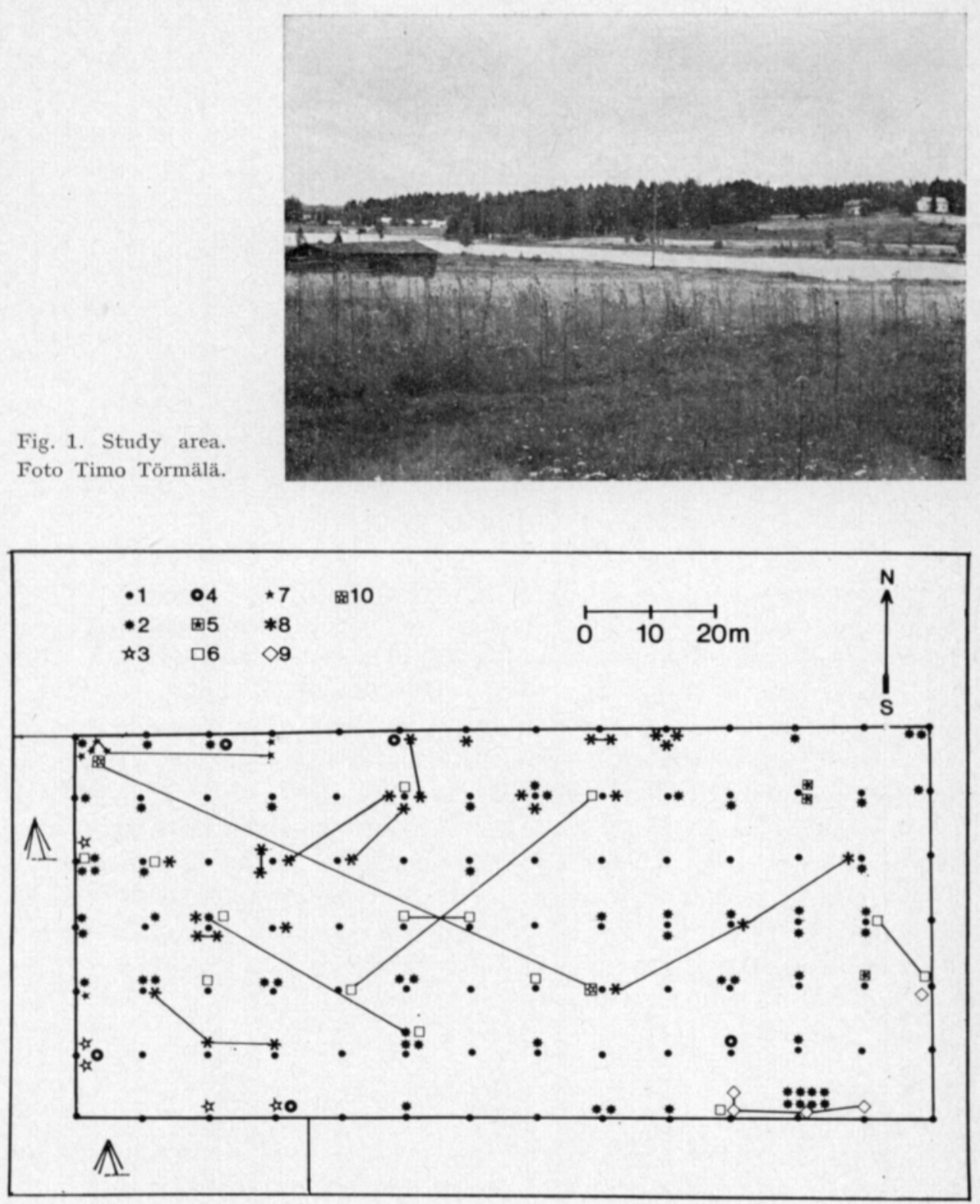

Fig. 2. Map of the study area and the catches of small mammals. 1. Trap site, 2. Sorex araneus, 3. S. isodon, 4. S. minutus, 5. Neomys fodiens, 6. Microtus agrestis, 7. Clethrionomys glareolus, 8. Micromys minutus, 9. Mus musculus, and 10. Mustela rixosa.

The samples were deep-frozen and sorted later by hand and tweezers. Agrostis (A. tenuis (>95\%), A. canina and A. stolonifera) and some Carex species (C. canescens, $C$. echinata, $C$. nigra and $C$. pallescens) were not identified when sterile. Neither were the mosses identified. Detritus was considered to consist of the loose litter on the ground and the non-living parts (brown) of the aboveground rooted vegetation. The sorted samples were allowed to dry in open paper bags in a dry room for three months. Thereafter they were weighed 
to nearest 0.1 gram. The water content of the air-dried samples was determined by drying ten samples in an $85^{\circ} \mathrm{C}$ oven. The mean water contents of the monocotyledons, dicotyledons and detritus were $6.3 \%, 5.8 \%$, and $6.0 \%$.

The results are given in absolute dry weights per square meter. Energy contents of the plant materials were not determined, but when changing dry weights into energy units, the constant $1 \mathrm{~g}$ dry plant material equal to 17.6 $\mathrm{kJ}$ or $4.2 \mathrm{kcal}$, was used (Cummins and Wurcheck 1971).

The biomasses of the different plant taxa were evenly distributed among the sampling sites. Only the green biomasses of Achillea millefolium, Agrostis spp. Carex spp., Festuca rubra, Poa pratensis s. lat. and Bryophyta had almost significant differences between the sampling sites. Only the detritus had a clearly uneven distribution $\left(\mathrm{F}=2.485^{* * *}\right)$.

The nomenclature of the vascular plants is according to EHRENDORFER (1973).

\subsection{Underground parts of vegetation}

The underground parts of vegetation were sampled by a soil auger from the midpoints of the clip-plots after clipping. Soil augers with an area of 100 or $150 \mathrm{~cm}^{2}$ and a depth of $20 \mathrm{~cm}$ were used. The underground parts of some plants penetrate far deeper than $20 \mathrm{~cm}$, but obviously more than $90 \%$ of the underground biomass was included into our samples (see Linkola and TIIRIKKA 1936, TRACZYK 1968). Golley (1960) took samples down to $15 \mathrm{~cm}$ and Wiegert and Evans (1964) to $20 \mathrm{~cm}$.

The underground parts of the vegetation were separated from the soil by a sieve set (mesh sizes 10,5 and $2.5 \mathrm{~mm}$ ) and a water jet. The ash content was determined by keeping root samples in $550^{\circ} \mathrm{C}$ oven for three days. The ash per cent was on the average $6.7 \pm 0.8 \%$, thus obviously very few mineral particles remained in the samples after washing. The biomasses of the underground vegetation are expressed in the same way as those of the aboveground vegetation.

\subsection{Arthropods}

The arthropods were sampled by a Burkard suction apparatus from $0.5 \mathrm{~m}$ high circular metal enclosure with an area of $0.25 \mathrm{~m}^{2}$ placed on the ground. A suction time of three minutes was used and the samples were taken beside the clip-plots before clipping. The sampling dates were the same as those for the vegetation, and every time one sample was taken from each of the twenty sampling sites. The suction apparatus broke down on 21 . VIII and only four samples could be taken; in addition 13 samples were taken on 2. VIII. The samples were always taken by the same person.

Heikinheimo and RaAtikainen (1962) have studied the efficiency of the suction method and compared it to the netting method. Suction samples are more reliable and give information on the actual densities. Among the disadvantages of the suction method may be mentioned the following: different ecolocigal and taxonomical groups do not enter the samples at equal efficiency and weather, and the quantity and quality of the vegetation greatly affect the 
efficiency. In addition many specimens are damaged. The quantitativity of suction samples was studied in this work by taking 3-4 samples from the same place, isolated by a cloth and the sampling enclosure, at intervals of about ten minutes. Using the method of ANDRZEJEWSKI and JEZIERSKI (1966) the efficiency of the first three minute suction could be estimated to be e.g. for leafhoppers $90 \%$, for Oribateid mites $70 \%$, for Collembolas $55 \%$ and for spiders $50 \%$. However, the results obtained from single suctions were not corrected by these values.

\subsection{Vertebrates}

The occurrence of small mammals was studied by catch-mark-recatch method. High trap mortality caused the failure of the method in shrews. Swedish Ugglan Special traps baited with cheese and dried apple were used. The trap sites are given in Fig. 2. Trapping was performed in six periods (in brackets the number of trapping nights per period): 29. IV -22 . V (4), 29. V -3 . VI (6), 18-22. VI (5), 18-21. VII (2), 22-25. VIII (4) and 5-8. X (4). The animals were identified, weighed and marked by clipping toes.

Observations on birds, amphibians and reptiles were made during the field work and some of the animals were weighed.

\subsection{Statistical calculations}

The data was treated statistically in the Computer Centre of the University of Jyväskylä. The following symbols for the levels of significance are used in the tests: $\mathrm{p}^{*}<.05, \mathrm{p}^{* *}<.01$ and $\mathrm{p}^{* * *}<.001$. The seasonal aspects of the leafhopper and vegetation communities were studied by the means of the following indices:

1) Sørensen's (1948) quotient of similarity $\mathrm{QS}=\frac{\Sigma 2 \mathrm{c},}{\Sigma \mathrm{a}+\mathrm{b}}$ where $\mathrm{a}$ is the amount of a species in sample 1

and $\mathrm{b}$ the amount of the same species in sample 2. $\mathrm{c}$ is the smaller of these two amounts. 2) RenKonen's (1938) index

PS $=\Sigma$ min. dom. a, b

PS is calculated by summing the smaller dominance values of taxa common to the communities compared.

\section{Results}

\subsection{Primary production}

Net primary production of the vegetation can be defined as follows:

$P_{n}=B_{2}-B_{1}+L+G$, where

$B_{1}=$ the standing crop of the vegetation at the moment $t_{1}$

$B_{2}=$ the standing crop of the vegetation at the moment $t_{2}$

$\mathrm{L}=$ losses of vegetation caused by withering and shedding during time $t_{2}-t_{1}$

$G=$ losses caused by herbivores during time $t_{2}-t_{1}$

$P_{n}=$ net primary production during $t_{2}-t_{1}$ 
In grassland studies the annual net primary production is often estimated to equal the maximum standing crop of the vegetation. In the reserved field the maximum green biomass on 21 July amounted to $328 \mathrm{~g} / \mathrm{m}^{2}$. By summing the peak green biomasses of the taxa the annual aboveground net primary production rises up to $405.2 \mathrm{~g} / \mathrm{m}^{2}$ (Table 1). The proportion of the monocotyledons was $59.8 \%$ and that of the dicotyledons $38.4 \%$. Mosses amounted to $1.3 \%$ and horsetails to $0.8 \%$. Altogether 60 species were identified from the samples. WiEgert and Evans (1964) have developed two methods for calculating the net production of the aboveground vegetation based on the decomposition rate of the detritus. In the reserved fields some rates could be calculated by adapting their sample pair method according to which

$$
\begin{aligned}
& r=\frac{\ln \left(W_{0} / W_{1}\right)}{t_{1}-t_{0}}, \text { where } \\
& r=\text { decomposition rate of detritus in mg/g.d } \\
& W_{0}=\text { the mean amount of detritus in clip-plots at sampling date } t_{0} \\
& W_{1}=\text { the mean amount of detritus in clip-plots at sampling date } t_{1} \\
& t_{1}-t_{0}=\text { the time interval between sampling dates } t_{3} \text { and } t_{1} \text { in days }
\end{aligned}
$$

The method was not applicable in mid-summer and autumn because new detritus was formed between the sampling dates. The following decomposition rates were obtained: 29 . IV -21 . V. $4.6 \mathrm{mg} / \mathrm{g}$.d, 22 . V-30. VI $5.2 \mathrm{mg} / \mathrm{g}$.d and during winter 26. IX 1973-9. V $19741.9 \mathrm{mg} / \mathrm{g}$.d. According to the simplified formula of WIEgERT and Evans (1964), the annual aboveground net primary production equals the mean amount (weighed) of detritus multiplied by the mean decomposition rate (weighed) of detritus. Using this formula the annual net primary production of the aboveground vegetation was $415 \mathrm{~g} / \mathrm{m}^{2}$, when the mean amount of detritus was $300 \mathrm{~g} / \mathrm{m}^{2}$ and the mean decomposition rate of detritus during summer was estimated to be $6.0 \mathrm{mg} / \mathrm{g}$.d on the basis of the above results.

The simplest way to estimate the production of underground parts of the vegetation is to subtract the minimum biomass from the maximum. In the reserved field this method yielded $343.4 \mathrm{~g} / \mathrm{m}^{2} . \mathrm{y}$. Thus, the net production of aboveground parts was 1.2 times as high that of the underground parts.

During successive sampling intervals the following changes in the aboveground green (living) vegetation were observed $\left(\mathrm{g} / \mathrm{m}^{2}\right): 29 . \mathrm{IV}-21 . \mathrm{V}(+19.5)$, 22. V-14. VI $(+97.3), 15-30$. VI $(4+151.3), 1-21$. VII $(+40.1), 22$. VII -13. VIII $(-18.3)$, 14. VIII-4. IX $(-18.6)$, and 5.-26. IX (-141.4). The rates expressed in $\mathrm{g} / \mathrm{m}^{2} . \mathrm{d}$ are given in Fig 3 . Until the end of June the growth of both aboveground and underground parts of the vegetation was accelerating. Thereafter the net changes in aboveground green vegetation decreased and turned negative by the end of July. The underground parts had a second growth maximum in August (Fig. 3). It should be noted that the curves do not represent rates of net production, although they roughly describe its seasonal distribution.

The sum of the aboveground and underground net production was 749 $\mathrm{g} / \mathrm{m}^{2}$, when the aboveground annual net production is estimated by summing the peak green biomasses of different taxa. This is equal to about $13200 \mathrm{~kJ}$ 
Table 1. Maximum, its date and percentage of the green biomass of plant taxa

\begin{tabular}{|c|c|c|c|}
\hline Taxon & $\mathrm{g} / \mathrm{m}^{2}$ & $\%$ & Date \\
\hline Achillea millefolium ................... & 4.8 & 1.2 & 21. VII \\
\hline A. ptarmica ......................... & 66.8 & 16.6 & 13. VIII \\
\hline Agrostis spp. ............................. & 53.0 & 13.2 & 30. VI \\
\hline Alchemilla spp. ...................... & .1 & .0 & 21. VII \\
\hline Alnus glutinosa ........................ & .0 & .0 & 30 . VI \\
\hline Angelica sylvestris ................... & 1.0 & .3 & 13. VIII \\
\hline Anthoxanthum odoratum ............ & .4 & .1 & 21. VII \\
\hline Carex leporina ........................ & 19.3 & 4.8 & 4. IX \\
\hline C. spp. .............................. & 13.8 & 3.4 & 13. VIII \\
\hline Cerastium holosteoides ............. & .1 & .0 & 13. VIII \\
\hline Leucanthemum vulgare s. lat...... & .0 & .0 & 13. VIII \\
\hline Cirsium heterophyllum ............. & 3.1 & .8 & 4. IX \\
\hline 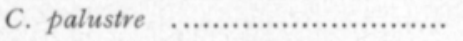 & 4.5 & 1.1 & 21. VII \\
\hline Deschampsia caespitosa ............. & 41.3 & 10.3 & 21. VII \\
\hline Agropyron repens .................... & 1.0 & .2 & 13. VIII \\
\hline Equisetum arvense ................... & 1.2 & .3 & 21. VII \\
\hline E. sylvaticum ......................... & 2.2 & .5 & 4. IX \\
\hline Euphrasia spp. ........................... & .0 & .0 & 30. VI \\
\hline Festuca rubra ......................... & 25.9 & 6.4 & 21. VII \\
\hline Filipendula ulmaria ................ & 16.0 & 4.0 & 21. VII \\
\hline Galeopsis sp. ......................... & .0 & .0 & 21. VII \\
\hline Galium uliginosum...$\ldots \ldots \ldots \ldots \ldots$ & 1.8 & .4 & 13. VIII \\
\hline Geranium sylvaticum ................ & 6 & .2 & 4. IX \\
\hline Geum rivale ............................ & .1 & .0 & 21. VII \\
\hline Glechoma hederacea .................. & .0 & .0 & 14. VI \\
\hline Hieracium pilosella s. lat. .......... & .2 & .0 & 30. VI \\
\hline H. umbellatum s. lat. ............... & .1 & .0 & 13. VIII \\
\hline Juncus filiformis .................... & 3.8 & 1.0 & 26. IX \\
\hline Lathyrus pratensis .................. & 5.8 & 1.4 & 14. VI \\
\hline Leontodon autumnalis ............... & 0 & .0 & 21. VII \\
\hline Luzula multiflora ..................... & .2 & .1 & 30. VI and 21. VII \\
\hline Phleum pratense ..................... & 26.6 & 6.61 & 13. VIII \\
\hline Plantago major ........................ & .0 & .0 & 13. VIII \\
\hline Poa pratensis s. lat. ................... & 55.9 & 13.9 & 30. VI \\
\hline Polygonum viviparum .............. & .1 & .0 & 21. VII \\
\hline Potentilla erecta ....................... & 2.1 & .5 & 21. VII \\
\hline Prunella vulgaris ..................... & .1 & .0 & 30. VI \\
\hline Ranunculus acris ....................... & 20.5 & 5.1 & 30. VI \\
\hline$R$. auricomus ...................... & 1.5 & .4 & 30. VI \\
\hline R. repens .............................. & 10.5 & 2.6 & 30. VI \\
\hline Rhinanthus minor ................... & .7 & .2 & 30. VI \\
\hline Rumex acetosa .......................... & .1 & .0 & 21. VII and 13 . VIII \\
\hline Salix phylicifolia ..................... & 5.1 & 1.3 & 30. VI \\
\hline Stellaria graminea ................... & .1 & .0 & 21. VII \\
\hline Taraxacum spp. ........................ & .2 & .1 & 21. VII \\
\hline Trifolium medium .................... & .1 & .0 & 26. IX \\
\hline T. pratense ............................ & .7 & .2 & 30. VI \\
\hline 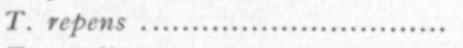 & 3.2 & .8 & 21. VII \\
\hline T. spadiceum ............................ & .3 & 1 & 30. VI \\
\hline Veronica chamaedrys ................. & .2 & .0 & 30. VI \\
\hline 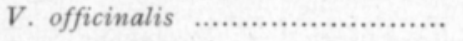 & .0 & .0 & 21. VII \\
\hline V. serphyllifolia $\ldots \ldots \ldots \ldots \ldots \ldots \ldots$ & .4 & .1 & 21. VII \\
\hline 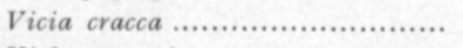 & 3.9 & 1.0 & 21. VII \\
\hline Viola arvensis ........................ & .1 & .0 & 21. VII \\
\hline V. palustris ............................. & .4 & .1 & 21. VII \\
\hline Bryophyta ............................ & 5.3 & 1.3 & 14. VI \\
\hline
\end{tabular}

Total

405.2

100.6 
or $3130 \mathrm{kcal}$. During 29 . IV -26 . IX the total radiation energy amounted to $2530000 \mathrm{~kJ} / \mathrm{m}^{2}$ at the Luonetjärvi weather observation station some 20 kilometres north of the study area. The net efficiency of the vegetation (primary producers) was thus $0.51 \%$. The efficiency was at its highest $15-30$. VI amounting to $0.9 \%$.

\subsection{Seasonal dynamics and aspects of the vegetation}

The seasonal dynamics of the main components of the vegetation are given in Fig. 4. The green biomass and underground parts of the vegetation presented striking seasonal variations. The amount of detritus decreased in spring and early summer when the temperature rose, reached its minimum during the summertime when the rates of development and the decomposition of detritus were equal, and began to increase rapidly in the beginning of September when the temperature began to drop. In winter when the aboveground vegetation was almost totally dead, detritus reached its maximum value (about $\left.450 \mathrm{~g} / \mathrm{m}^{2}\right)$. The green biomass of the dicotyledons had a more distinct peak than the monocotyledons, whose biomass remained even from the beginning of July to the beginning of September. The proportion of the green biomass of total biomass, excluding detritus, was highest on 21 July amounting to $38.4 \%$.

On the basis of curves describing seasonal variations in the green biomasses and percentages of plants, the taxa could be divided into five categories (Figs. 5 and 6):

1) Short, sharp maximum in mid-summer. Fast growth, short maximum period and rapid withering was characteristic of Achillea millefolium, Trifolium repens, Potentilla erecta, Cirsium palustre, Ranunculus

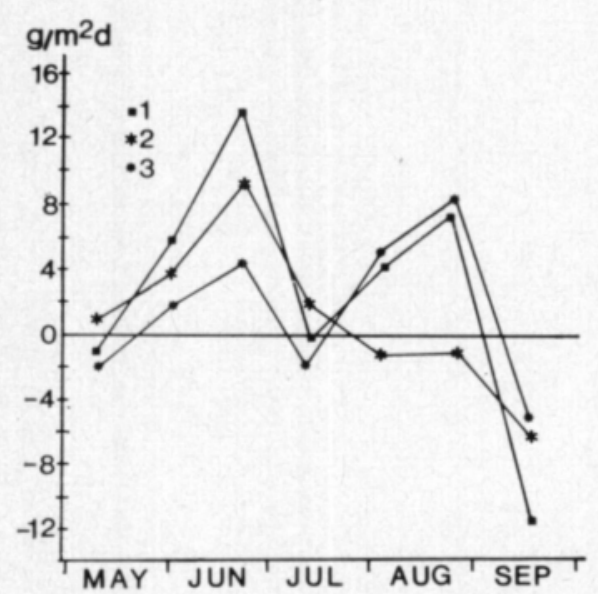

Fig. 3. Daily net changes $\left(\mathrm{g} / \mathrm{m}^{2}\right)$ in green biomass (2), underground biomass (3) and in their sum (1) during sampling intervals.

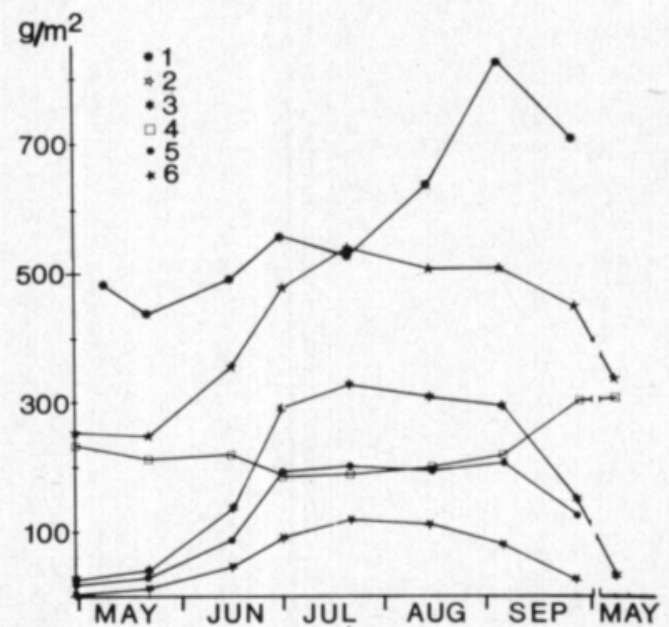

Fig. 4. Seasonal dynamics of the main components of vegetation. 1. Underground parts of vegetation, 2. Total aboveground vegetation (detritus plus green vegetation), 3. Total green biomass, 4. Detritus, 5. Monocotyledons, and 6. Dicotyledons. 

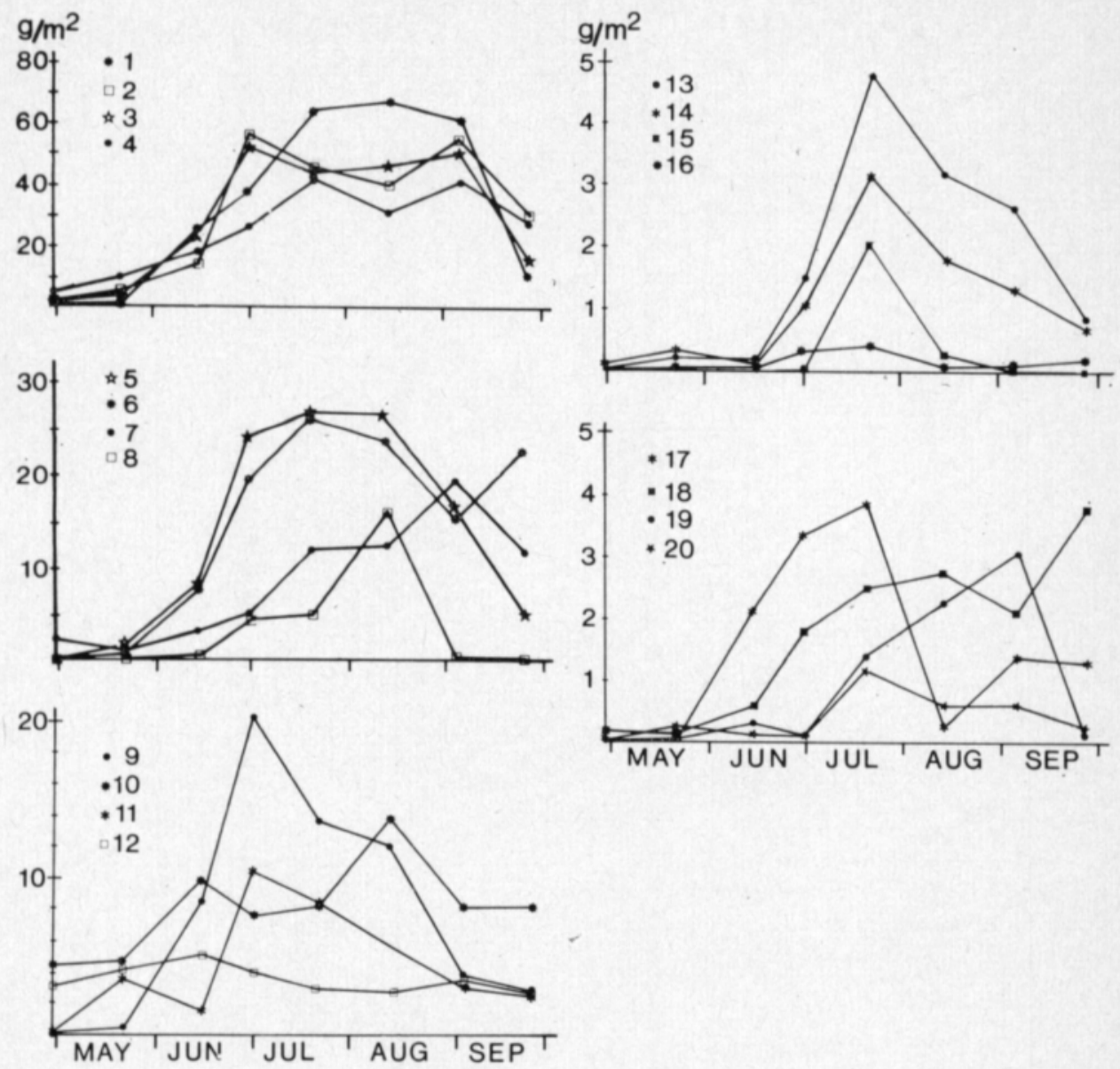

Fig. 5. Dynamics of the green biomass of plant taxa. 1. Achillea ptarmica, 2. Poa pratensis s. lat., 3. Agrostis spp., 4. Deschampsia caespitosa, 5. Phleum pratense, 6. Festuca rubra, 7. Carex leporina, 8. Filipendula ulmaria, 9. Ranunculus repens, 10. Carex spp., 11. Ranunculus acris, 12. Bryophyta, 13. Achillea millefolium, 14. Trifolium repens, 15. Potentilla erecta, 16. Anthoxanthum odoratu m, 17. Cirsium palustre, 18. Juncus filiformis, 19. Cirsium heterophyllym, and 20. Equisetum arvense.

acris, and $R$. repens. All the species were dicotyledonous and none of then had a high biomass. Their percentages were highest in spring, early summer or sometimes mid-summer.

2) Parabel shaped biomass curve. The increase and decrease of the green biomass was slower than in the previous group. Achillea ptarmica, Phleum pratense, and the rarely occurring Anthoxanthum odoratum belonged to this group. Achillea ptarmica was the most abundant taxon and Phleum pratense the fifth. The proportion of the species was highest in midsummer.

3) Long maximum. Agrostis spp., Poa pratensis s. lat., and Deschampsia caespitosa had long maxima, which probably included weak minima. However, the bimodality of the curves is not statistically significant. 

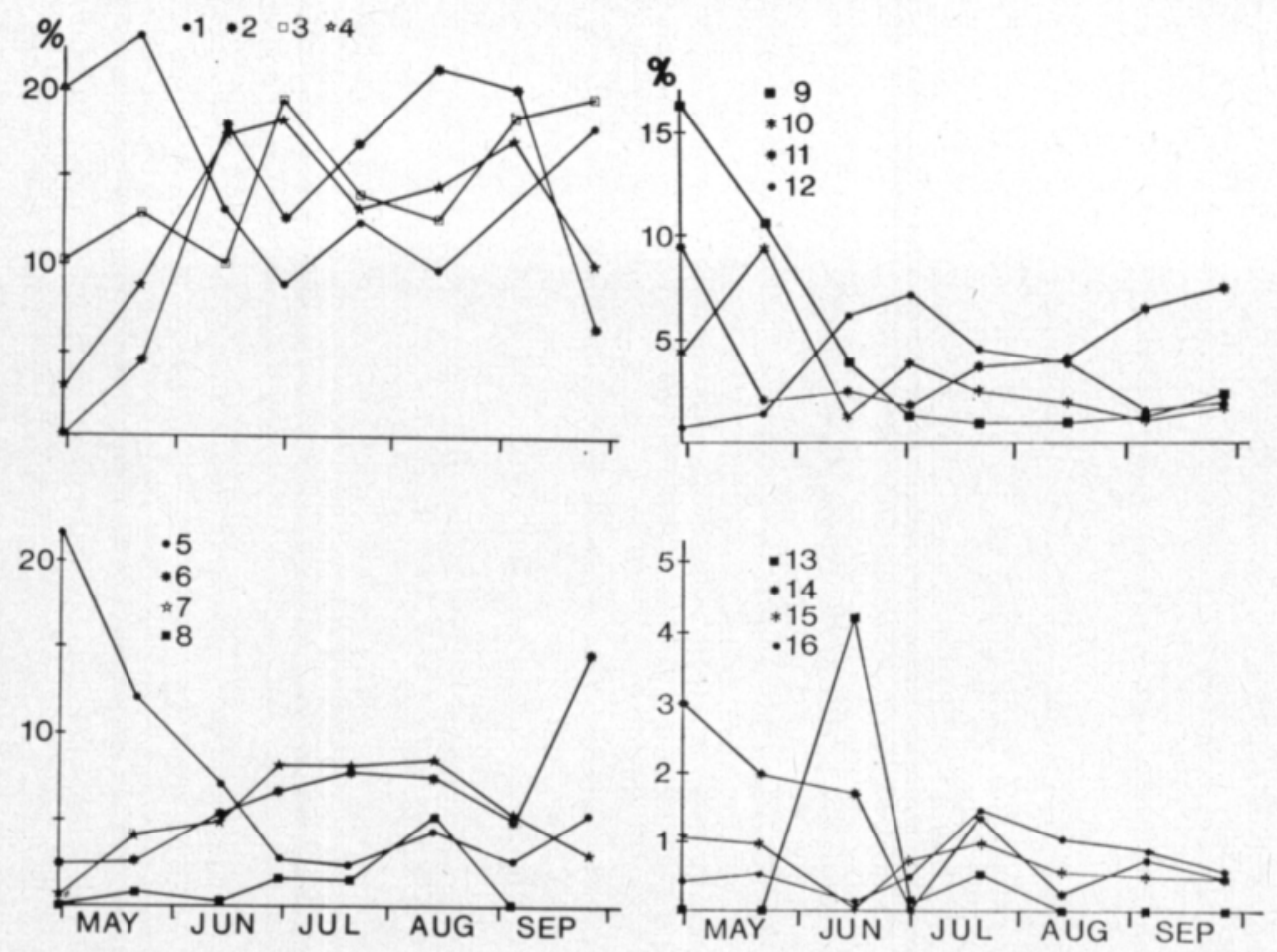

Fig. 6. Seasonal changes in the dominance values of plant taxa. 1. Deschampsia caespitosa,

2. Achillea ptarmica, 3. Poa pratensis s. lat., 4. Agrostis spp., 5. Carex spp., 6. Festuca rubra, 7. Phleum pratense, 8. Filipendula ulmaria, 9. Bryophyta, 10. Ranunculus repens, 11. Carex leporina, 12. Ranunculus acris, 13. Lathyrus pratensis, 14. Crisium palustre, 15. Trifolium repens, and 16. Achillea millefolium.

The percentage curve of Deschampsia caespitosa differs clearly from those of the species in the previous groups, since the green biomass of this species was high already early in the spring and it remained high until late autumn. The percentage of $\mathrm{Poa}$ varied, but generally it increased towards autumn. Agrostis spp. had maximum dominance values in mid-summer and its precentage curve greatly resembles that of Achillea ptarmica. Festuca rubra had its maxima at the end of July and in September. The difference between summer minimum and maximum is almost significant $\left(t=1.58^{\circ}\right)$. The percentage of the species was in maximum on 29. IX during the wet season preceded by an unusually dry July. The taxa in this as well as in the previous group were dominants and the second and third groups resemble each other by and large.

4) Late maximum. Carex spp., C. leporina, Juncus filiformis, Cirsium heterophyllum and Filipendula ulmaria belong to this heterogenic group. Carex spp. had biomass maximum on 13. VIII and the highest percentage value on 29. IV. Carex leporina had its peak biomass 5. IX after an even growth, and its proportion was highest on 29 April. The taxa of this group grow often on wet or moist sites. Their green biomass was low and reached its maximum in late summer.

5) No c l e a r m a x i m u m. Of the most important taxa, only Bryophyta did not have a clear maximum period. The proportion of mosses was greatest in spring and it rose again in the autumn after a long summer minimum. 
Vegetation can be divided into seasonal aspects in many ways. On the basis of the amount of green biomass and its changes, four aspects corresponding to the four seasons were separated (see Fig. 4).

1) Growth period. The amount of green biomass increased rapidly and production was high (approximate time limits in 197325 . V-30. VI).

2) M a x i m u period. Green biomass remained even at the level of about $300 \mathrm{~g} / \mathrm{m}^{2}$ and production was quite high, but also large amounts of new detritus were formed (1. VII-5. IX).

3) Withering period. Green biomass decresed rapidly and production was low $(6 . \mathrm{IX}-15 . \mathrm{X})$.

4) M i n i m m period. Green biomass was very low (under $50 \mathrm{~g} / \mathrm{m}^{2}$ ) and production was negligible $(1 . \mathrm{I}-25$. V and 15. IX-31. XII).

Vegetations of the different sampling dates were compared also with Sørensen's quotient of similarity and Renkonen's index (Table 2.). The vegetation was quite even throughout the season, but on the basis of both indices three aspects can be formed.

Table 2. Similarity of vegetation samples of different sampling dates according to Sørensen's (on the right side of the diagonal) and Renkonen's indices (on the left side).

\begin{tabular}{|c|c|c|c|c|c|c|c|c|}
\hline & 29. IV & 21. V & 14. VI & 30. VI & 21. VII & 13. VIII & 4. IX & 26. IX \\
\hline 29. IV & 100 & 61 & 25 & 12 & 11 & 12 & 13 & 22 \\
\hline 21. V & 72 & 100 & 43 & 23 & 21 & 22 & 23 & 39 \\
\hline 14. VI & 48 & 62 & 100 & 59 & 55 & 55 & 56 & 63 \\
\hline $30 . \mathrm{VI}$ & 39 & 57 & 76 & 100 & 81 & 79 & 80 & 63 \\
\hline 21. VII & 44 & 61 & 69 & 82 & 100 & 89 & 84 & 60 \\
\hline 13. VIII & 40 & 54 & 73 & 79 & 89 & 100 & 82 & 60 \\
\hline 4. IX & 46 & 58 & 80 & 79 & 84 & 82 & 100 & 61 \\
\hline 26. IX & 56 & 66 & 64 & 69 & 69 & 64 & 72 & 100 \\
\hline
\end{tabular}

1) A u t u m n, spring, and winter veget a t i o n. The reserved field belonged to this aspect on 29. IV and 21. V. Deschampsia caespitosa (20.1 and $23.1 \%$ ), Carex spp. (21.5 and $11.9 \%$ ), Bryophyta (16.1 and $10.5 \%)$, Carex leporina (9.4 and $1.9 \%$ ), Poa pratensis s. lat. (10.5 and $13.3 \%$ ), Ranunculus repens (4.2 and $9.4 \%$ ), and $R$. acris (3.8. and $8.7 \%$ ) dominated.

2) E a r ly summer vegetation. The samples taken on 14 and 30 June represent the early summer aspect. The dominating taxa were Achillea ptarmica (17.9 and $12.9 \%)$, Agrostis spp. (17.6 and $18.3 \%), D e-$ schampsia caespitosa (13.2 and $8.8 \%$ ), Poa pratensis, s. lat. (10.1 and $19.3 \%$ ), Festuca rubra (5.4 and $6.7 \%$ ), Phleum pratense (5.0 and $8.2 \%$ ), and Ranunculus acris $(6.1$ and $7.1 \%)$.

3) Mid-and late summer vegetation. Samples taken on 21. VII, 13. VIII, and 4. IX represent clearly this aspect. The most abundant taxa were Achillea ptarmica $(19.2-21.3 \%)$, Poa pratensis s. lat. (12.5-18.6 \%), Agrostis spp. (13.1-17.1\%), Deschampsia caespitosa $(9.6-13.7 \%)$, Phleum pratense $(5.2-8.6 \%)$, and Festuca rubra $(5.0-7.8 \%)$. Vegetation on the 
last sampling day (26. IX) resembled also the first aspect. The dominating taxa were Poa prantensis s. lat. (19.6\%), Deschampsia caespitosa $(17.9 \%$, Festuca rubra $(14.7 \%)$, Agrostis spp. (10.0\%) and Carex leporina $(7.4 \%)$.

\subsection{Arthropods}

The seasonal dynamics of the most abundant arthropod groups are presented in Fig. 7. In addition, representatives of Phalangida ( 3 specimens), Lepidoptera (3), Thysanoptera (11), and Orthoptera (3) were obtained from the suction samples.

The maximum of the mites was on 21. VII when their density amounted to $16000 / \mathrm{m}^{2}$. The difference between the sampling dates was clear $(\mathrm{F}=$ 11.61***). Most mites were Oribateids.

Springtails had their peak density $2529 / \mathrm{m}^{2}$ on 21 . V. The maximum differed clearly from the values of the preceding and the following sampling times $\left(\mathrm{t}=4.61^{* * *}\right.$ and $\left.\mathrm{t}=4.95^{* * *}\right)$.

The number of spiders decreased until the end of June, thereafter their amount increased up to the beginning of August $\left(42.8 / \mathrm{m}^{2}\right)$.

The curve representing seasonal dynamics of the beetles is almost identical with that of the spiders. The greatest density, $37.0 / \mathrm{m}^{2}$, was on 13 . VIII. The most abundant species was Apion marchicum Hbst. Altogether 164 specimens of this species, which hibernates when adult, were obtained, and the peak density $7.8 / \mathrm{m}^{2}$ was on 13 . VIII. Other Apion species were A. apricans Hbst, A. assimile Kby, A. cerdo Gerst., A. flavipes Payk., and A. simile Kby, whose total amount in 157 suction samples was 32 . After Curculionidae the next abundant beetle family was Staphylinidae. The number of Coleoptera larvae increased rapidly at the end of July, and increased thereafter slowly. The larvae were not determined, but obviously most of them belonged to the family Chrysomelidae.

The peak density of Diptera was $32.6 / \mathrm{m}^{2}$ on 30 . VI, and the difference between the sampling dates was clear $\left(\mathrm{F}=20.46^{* * *}\right)$.

The seasonal dynamics of Hymenoptera were quite similiar to those of Diptera: maximum $43.6 / \mathrm{m}^{2}$ on 30 . VII and $\mathrm{F}=10.61 * * *$. Fig. 7 does not include 348 Myrmica laevinodis Nyl. specimens in a suction sample on 13. VIII.

The most important bug species was Halticus apterus L. The bugs were most abundant on 21 . VII when their total density was $59 / \mathrm{m}^{2}$ and the density of Halticus apterus $24 / \mathrm{m}^{2}$ The difference between the sampling dates was very clear $\left(\mathrm{F}=43.71^{* * *}\right)$. The maximum period of Heteroptera nymphs started already at the beginning of June, but obviously because of methodological reasons their peak density was lower than that of the adults.

The maxima of Aphidina and Psyllina were on 30. VI, when their densities amounted to 24.6 and $8.2 / \mathrm{m}^{2}$.

Leafhoppers were the most important invertebrates of the field stratum, and the most abundant species were Arthaldeus pascuellus (Fn.), Elymana sulphurella (Zett.), Streptanus sordidus (Zett.), Agallia brachyptera (Bh.), Muellerianella brevipennis (Bh.), Aphrodes flavostriatus, (Don.), Diplocolenus abdominalis (F.), Deltocephalus pulicaris (Fn.), and Paluda preyssleri (H.-S.), 

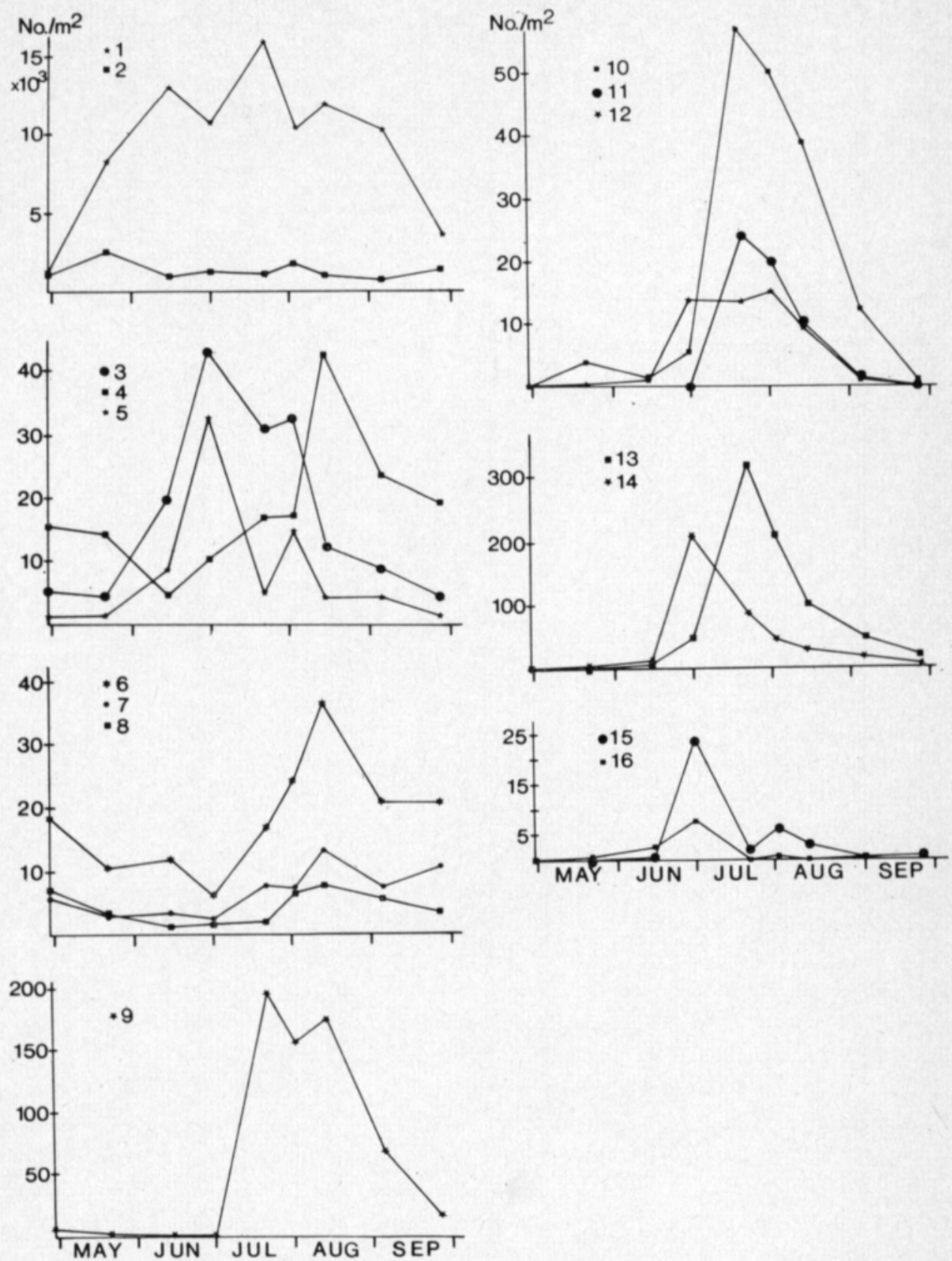

Fig. 7. Seasonal dynamics in abundance of the most artropod invertebrate taxa. 1. Acarina, 2. Collembola, 3. Hymenoptera, 4. Araneae, 5. Diptera, 6. Coleoptera, 7. Staphylinidae, 8. Apion marchicum, 9. Coleoptera larvae, 10. Heteroptera, 11. Halticus apterus, 12. Heteroptera nymphs, 13. Auchenorrhyncha, 14. Auchenorrhyncha nymphs, 15. Aphidina, and 16. Psyllina.

In total, 2128 leafhoppers belonging to 28 species were obtained from the suction samples. Differences between sampling dates were both in adults and in nymphs very clear $\left(\mathrm{F}=105.5^{* * *}\right.$ and $\left.68.12^{* * *}\right)$. The maximum of the 
Table 3. Mean (29. IV-26. IX) and maximum abundances of the most important artropods and the time of maximum.

\begin{tabular}{|c|c|c|c|}
\hline Taxon & $\begin{array}{c}\overline{\mathrm{X}} \\
\text { No. } / \mathrm{m}^{2}\end{array}$ & No. $/ \mathrm{m}^{2}$ & Date \\
\hline Araneida ............ & 18.5 & 42.8 & 13. VIII \\
\hline 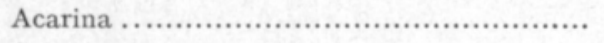 & 9163.5 & 16176.0 & 21. VII \\
\hline 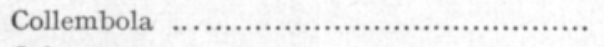 & 1297.5 & 2529.8 & 21. V \\
\hline Coleoptera ......................................... & 16.7 & 37.0 & 13. VIII \\
\hline Apion marchicum ............................. & 4.2 & 7.8 & 13. VIII \\
\hline Staphylinidae .............................. & 6.4 & 13.4 & 13. VIII \\
\hline Coleoptera, larvae ................................. & 55.7 & 199.0 & 21. VII \\
\hline 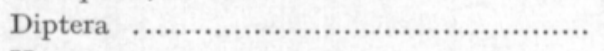 & 7.9 & 32.6 & 30. VI \\
\hline 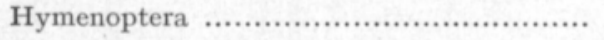 & 16.4 & 43.6 & 30. VI \\
\hline 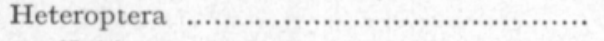 & 14.4 & 59.0 & 21. VII \\
\hline 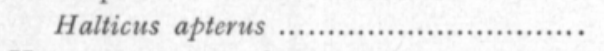 & 4.3 & 24.0 & 21. VII \\
\hline  & 5.2 & 15.7 & 2. VIII \\
\hline Psyllina ......................................... & .5 & 8.2 & 30. VI \\
\hline 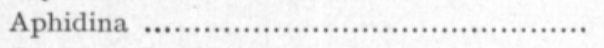 & 4.0 & 24.6 & 30. VI \\
\hline Auchenorrhyncha .................................. & 61.4 & 329.0 & 21. VII \\
\hline Agallia brachyptera ........................... & 5.3 & 38.0 & 21. VII \\
\hline Aphrodes flavostriatus ...................... & 5.1 & 22.0 & 21. VII \\
\hline Arthaldeus pascuellus ...................... & 11.5 & 73.0 & 21. VII \\
\hline Diplocolenus abdominalis .................. & 4.5 & 24.4 & 30. VI \\
\hline Elymana sulphurella ....................... & 9.4 & 64.0 & 21. VII \\
\hline Muellerianella brevipennis .................. & 5.1 & 31.7 & 2. VIII \\
\hline Streptanus sordidus ......................... & 6.7 & 50.0 & 21. VII \\
\hline Auchenorrhyncha, nymphs ................... & 44.9 & 217.0 & 30. VI \\
\hline
\end{tabular}

nymphs was noticeably lower than the peak density of the adults, probably because the suction method is less effective on nymphs.

The mean (weighed) densities, the maxima and the dates of the most abundant invertebrates are presented in Table 3 .

The leafhopper species can be grouped into three phenological categories on the basis of the times of their maximum abundance (see Fig. 8).

1) Maximum in early summer. Doliotettix pallens (Zett.) was the first to reach the maximum abundance (on 14 . VI $4.8 / \mathrm{m}^{2}, 74.7 \%$ of the leafhoppers). The species hibernates at the nymphal stage. Diplocolenus abdominalis $\left(24.4 / \mathrm{m}^{2}, 50.6 \%\right)$, Aphrodes bifasciatus (L.) $\left(7.6 / \mathrm{m}^{2}, 15.7 \%\right)$, Stiroma bicarinata (H.-S.) $\left(5.8 / \mathrm{m}^{2}, 12.0 \%\right)$, and Javesella forcipata (Bh.) $\left(1.6 / \mathrm{m}^{2}\right.$, $3.3 \%$ ) had their maxima on 30 . VI. The species of this group hibernate as nymphs or eggs.

2) M aximum in mid-summer. The four most abundant leafhopper species of the studied reserved field had almost identical seasonal dynamics, and not a single adult specimen was found before 21. VII, when the species had their maxima. The abundances and dominances of the species were then the following: Arthaldeus pascuellus $73 / \mathrm{m}^{2}, 22.1 \%$, Elymana sulphurella $64 / \mathrm{m}^{2}, 17.0 \%$, Streptanus sordidus $50 / \mathrm{m}^{2}, 15.1 \%$ and Agallia brachyptera $38 / \mathrm{m}^{2}, 11.5 \%$. In addition to these species also Deltocephalus pulicaris $21 / \mathrm{m}^{2}$, $6.3 \%$, Aphrodes flavostriatus $22 / \mathrm{m}^{2}, 6.7 \%$, Paluda flaveola (Bh.) $6 / \mathrm{m}^{2}, 2.7 \%$, 

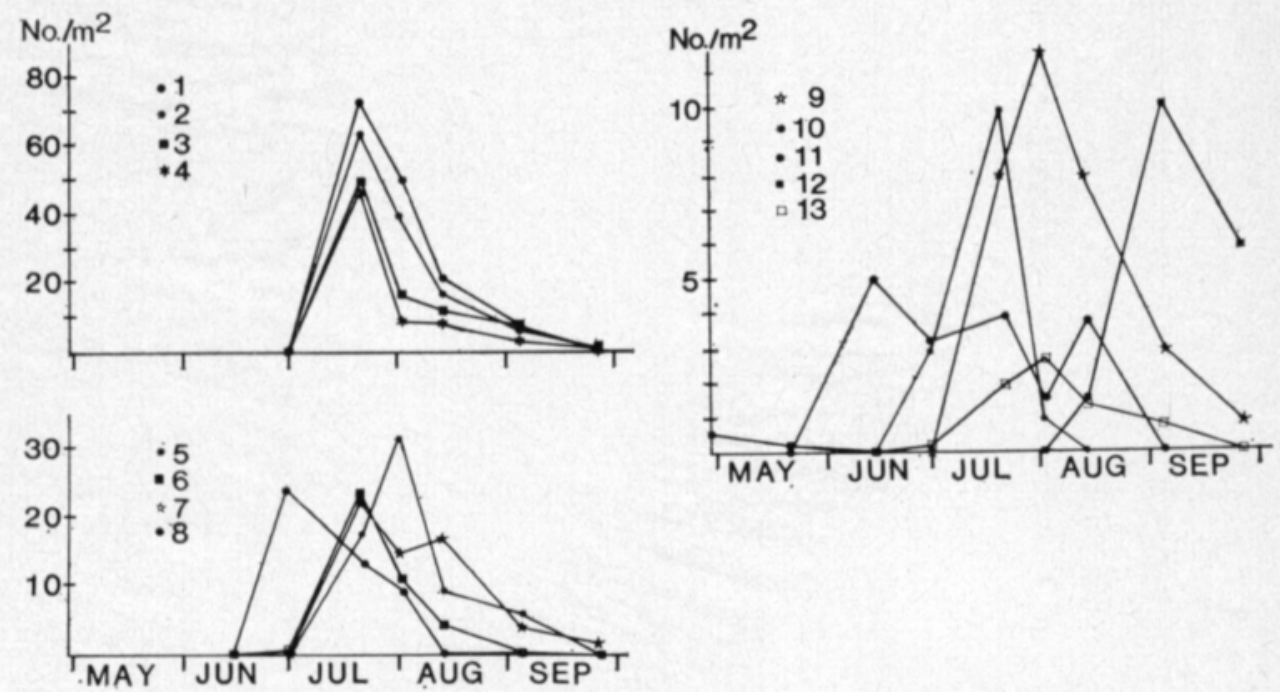

Fig. 8. Seasonal dynamics in abundance of the most important leafhopper species. 1. Arthaldeus pascuellus, 2. Elymana sulphurella, 3. Streptanus sordidus, 4. Agallia brachyptera, 5. Muellerianella brevipennis, 6. Deltocephalus pulicaris, 7. Aphrodes flavostriatus, 8. Diplocolenus abdominalis, 9. Paluda preyssleri, 10. Paluda flaveola, 11. Doliotettix pallens, 12. Delphacodes venosus, and 13. Philaenus spumarius.

Aphrodes bicinctus (Schrk.) $4 / \mathrm{m}^{2}, 1.2 \%$, Evacanthus interruptus (L.) $3 / \mathrm{m}^{2}$, $0.9 \%$, and Balclutha punctata (Thb.) $1 / \mathrm{m}^{2}, 0.3 \%$ had their maxima on 21 . July. Muellerianella brevipennis $\left(31 / \mathrm{m}^{2}, 15.0 \%\right)$, Paluda preyssleri $\left(11 / \mathrm{m}^{2}\right.$, $5.5 \%)$, and Notus flavipennis (Zett.) $\left(2 / \mathrm{m}^{2}, 1.0 \%\right)$ reached their maxima on 2. VIII. The leafhoppers of this group hibernate as eggs with the exception of Balclutha punctata which hibernates as adult.

3) M a i m u in lat e summer. Only Delphacodes venosus (Gm.) had its maximum in late summer. On 4. IX the species amounted to $9.2 / \mathrm{m}^{2}$ corresponding to $18.8 \%$ of the total leafhopper fauna. On 26. IX its percentage was $44.6 \%$ in spite of the reduced density. In spring, on 29 April and 21 May, the species was the only leafhopper occurring as adult.

The leafhopper faunas of the different sampling dates were compared by means of Renkonen's and Sørensen's indices (Table 4), and three seasonal communities were distinguished.

1) A utumn, winter and spring aspect. The only species of the community occurring at the adult stage was Delphacodes venosus. The nymphs of Doliotettix pallens and Stiroma bicarinata also belonged to this aspect, which occurred from the beginning of the year to the end of May, and again from the end of September to the end of the year.

2) Early summer aspect. This aspect was characterized by Doliotettix pallens and Diplocolenus abdominalis and it lasted from the beginning of June to the beginning of July. During this period many changes in species composition and abundances took place and so the aspect is quite non-uniform. Other species typical to the early summer aspect were Stiroma bicarinata, Aphrodes flavostriatus, and Javesella forcipata. 
Table 4. Similarity of leafhopper fauna of different sampling dates according to Sørensen's (on the right side of the diagonal) and Renkonen's indices (on the left side).

\begin{tabular}{|c|c|c|c|c|c|c|c|c|c|}
\hline & 29. IV & 21. V & 14. VI & 30. VI & 21. VII & 2. VIII & 13. VIII & 4. IX & 26. IX \\
\hline 29. IV & 100 & 33 & 00 & 00 & 00 & 00 & 00 & 10 & 15 \\
\hline 21. V & 100 & 100 & 00 & 00 & 00 & 00 & 00 & 01 & 03 \\
\hline 14. VI & 00 & 00 & 100 & 16 & 03 & 02 & 08 & 01 & 02 \\
\hline 30. VI & 00 & 00 & 18 & 100 & 12 & 11 & 07 & 02 & 01 \\
\hline 21. VII & 00 & 00 & 02 & 09 & 100 & 71 & 49 & 21 & 03 \\
\hline 2. VIII & 00 & 00 & 02 & 07 & 80 & 100 & 64 & 30 & 06 \\
\hline 13. VIII & 01 & 01 & 06 & 06 & 77 & 76 & 100 & 51 & 12 \\
\hline 4. IX & 19 & 19 & 01 & 02 & 68 & 69 & 74 & 100 & 37 \\
\hline 26. IX & 45 & 45 & 03 & 04 & 41 & 39 & 43 & 62 & 100 \\
\hline
\end{tabular}

3) M id- and late summer as pect. Arthaldeus pascuellus, Agallia brachyptera, Elymana sulphurella, Streptanus sordidus, Aphrodes flavostriatus, Deltocephalus pulicaris, Muellerianella brevipennis, Evacanthus interruptus, and Philaenus spumarius belonged to the uniform aspect lasting from the middle of July to the end of September.

\subsection{Vertebrates}

Trap sites and total catches per trap are shown in Fig 1. Table 5 shows the catches per trapping period.

The most numerous of the small mammals in the reserved field was Sorex araneus L., totalling 60 separate inviduals in the catches. The trap mortality was high and only one specimen was recaptured. The sex ratio among the $\mathbf{5 1}$ studied individuals was 25 males to 26 females. The majority of the shrews had been born in the study year. The seasonal maximum occurrence of the

Table 5. The catches of different trapping periods per 100 trap nights. Every individual has been taken in account only once during each trapping period. Number of trapping nights per period is in the paranthesis.

\begin{tabular}{|c|c|c|c|c|c|c|}
\hline 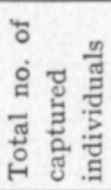 & 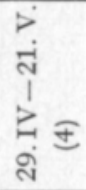 & $\begin{array}{l}5 \\
\text { mi } \\
1 \\
>0 \\
\text { ले }\end{array}$ & 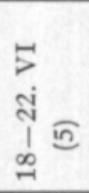 & $\begin{array}{l}\text { J } \\
\text { ป } \\
\text { I } \\
1\end{array}$ & 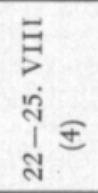 & $\begin{array}{l}x \\
\infty \\
1 \\
\text { in }\end{array}$ \\
\hline 60 & - & - & 1.20 & 5.50 & 6.00 & 4.50 \\
\hline 5 & - & - & .20 & - & 1.00 & - \\
\hline 5 & - & 16 & - & .50 & .75 & - \\
\hline 3 & - & - & - & - & .25 & .50 \\
\hline 2 & - & .16 & .20 & - & - & - \\
\hline 18 & - & .50 & - & - & 1.50 & 2.25 \\
\hline 12 & 1.25 & .50 & .40 & - & .50 & - \\
\hline 4 & - & - & - & - & .25 & .75 \\
\hline 1 & - & - & - & - & .25 & - \\
\hline 110 & 1.25 & 1.33 & 2.00 & 6.00 & 10.50 & 8.00 \\
\hline
\end{tabular}


species was at the end of August. The species had a fairly uniform distribution in the study field, however, the best trap yielded six shrews and the upper part of the field somewhat more than the lower.

The field vole (Microtus agrestis) population was still in the spring quite normal (about $10-15 /$ ha), but in the summer the species disappeared totally. This might have been due to pygmy weasels (Mustela rixosa) nesting in a barn at the edge of the study area.

Saxicola rubetra (L.) and Motacilla flava L. nested in the study area. Corvus corone L., Carpodacus erythrinus, (Pall.) and Emberiza schoeniclus (L.) were seen occasionally. Five Bufo bufo (L.) were trapped in connection with the small mammal trapping and several Lacerta vivipara Jacq. specimens were met during the field work.

\section{Discussion}

\subsection{Primary production}

Studies in grassland ecosystems comparable to the present one have been published e.g. by Golley $(1960,1965)$, Wiegert and Evans (1964), Traczy K (1968, 1971), Gyllenberg (1969) and Kosonen (1969). Golley (1960) studied the energy dynamics of a food chain in an old field in Michigan. He used the maximum standing crop of the green vegetation as an estimate for aboveground net primary production. He calculated the underground production by subtracting the minimum biomass from the maximum. In a comprehensive study on the structure and function of a broomsedge (Andropogon) community Golley (1965) summed the maximum biomasses of different taxa to get an estimate of the net production of the aboveground vegetation. The underground production was approximated in the same way as in his earlier work. Gyllenberg (1969) used the maximum biomass of rooted living and dead vegetation as an estimate of aboveground net primary production. Kosonen (1969) gives the total standing crop of aboveground vegetation including living and dead parts of the vegetation as net production. TRACZYK (1971) used the maximum green standing crop as a value for primary production. In mowed fields he calculated the production by summing the yields of three successive mowings. WIEgERT and Evans (1964) based the net primary production in two ways on the decomposition rate of detritus. The study was made on a waste field in Michigan. TRACZYK (1968) calculated the aboveground vegetation in six different methods in a moist meadow community in Poland.

In the present study the vegetation was sorted according to the method of WiEgert and Evans (1964) and TRACZYK (1968), and the annual net production of the aboveground vegetation was calculated by summing the peak biomasses and by the shorter formula of Wiegert and Evans (1964). The results of the above mentioned studies are given in Table 6 . When comparing the results the geographical and climatical differences the as well as variations in methods and terminology should be taken into account. None of the figures include the consumption of the herbivores. In the reserved field the herbivores consumed probably only few per cents of the net production. 
Table 6. Results of studies on primary production on meadow ecosystems. $\mathrm{B}=$ maximum standing rop, $\mathrm{P}=$ net production per year or growing season, $\mathrm{a}=$ aboveground and $\mathrm{b}=$ underground parts of vegetation. All figures $\mathrm{g} / \mathrm{m}^{2}$. Further details in the text.

\begin{tabular}{|c|c|c|c|c|}
\hline Study & $\mathrm{B}_{\mathrm{a}}$ & $\mathrm{P}_{\mathrm{a}}$ & $\mathrm{B}_{\mathrm{u}}$ & $\mathrm{P}_{\mathrm{u}}$ \\
\hline GoLLEx $(1960)$ in $1956 \ldots \ldots .$. & 385 & 385 & - & - \\
\hline 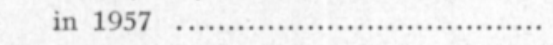 & 251 & 251 & 2516 & 1023 \\
\hline 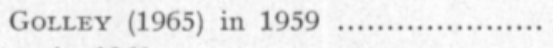 & 253 & 493 & - & 157 \\
\hline in 1960 .................................... & 191 & 508 & - & 118 \\
\hline in 1962 & 95 & 497 & - & 171 \\
\hline 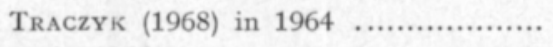 & 163 & $153-356$ & 822 & 302 \\
\hline in 1965 & 193 & $193-345$ & - & - \\
\hline GYLLENBERG (1969) in $1966 \ldots \ldots \ldots \ldots \ldots . . . .$. & 371 & 371 & - & - \\
\hline  & 536 & 536 & - & - \\
\hline in 1968 ................................. & 497 & 497 & 709 & - \\
\hline Kosonen (1969) Geum area ............. & 527 & 895 & - & - \\
\hline Arrhenatherum area ..................... & 485 & 740 & - & - \\
\hline Calamagrostis area ........................ & 625 & 1095 & - & - \\
\hline Anthriscus area ......................... & 441 & 797 & - & - \\
\hline TRACZYK (1971) natural meadow ....... & 476 & 476 & - & - \\
\hline hay field I ................................ & - & 536 & - & - \\
\hline hay field II ............................. & - & 585 & - & - \\
\hline \multicolumn{5}{|l|}{ WIEGERT \& Evans (1964) area I in } \\
\hline 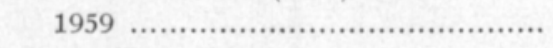 & 115 & 305 & - & - \\
\hline 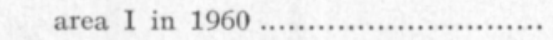 & 133 & 320 & 685 & 143 \\
\hline 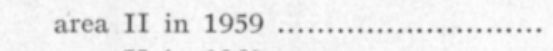 & 229 & 943 & - & - \\
\hline 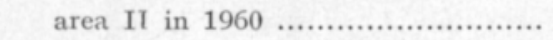 & 217 & 1064 & 1018 & 358 \\
\hline 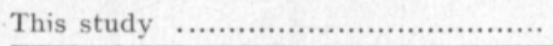 & 328 & $405-415$ & 827 & 345 \\
\hline
\end{tabular}

Each of the above mentioned variations of the harvesting method has its advantages and disadvantages. Measuring of the total aboveground peak biomass including the living and the dead material (e.g. Kosonen 1969) is the cheapest method, because sorting of the vegetation is not necessary. This method has, however, many serious sources of error, e.g. the detritus of the previous year is partly included in the production. The method based on the measuring of the peak green biomass is also cheap, because one sampling is sufficient, but it gives reliable results only in ecosystems where few species with a similar growth rhythm dominate. The method is more applicable in areas with a short growing season than in areas where the growing and dying take place almost throughout the year. This method was employed in the study of the regional productivity of Finnish hayfields (RAATIKaINEN and RAatikainen 1975). The mean aboveground yield of the hays was $335 \mathrm{~g} / \mathrm{m}^{2}$ in dry weight, which is $7 \mathrm{~g}$ more than the yield (standing crop) of green vegetation in the reserved field at the corresponding time.

Summing the peak biomasses of the invidual species or taxa gives a more accurate picture of the production, because it takes into account the fact that different species reach the peak biomass at differing times. The method is more laborious than the previous ones as it requires several samplings and careful sorting of the samples. The main error of this method lies in the differences in 
growth rhythm among invidual plants of the species. According to Traczy K (1968) also spatial variation in vegetation may cause too high peaks if the number of samples is not very large. This method yielded in the reserved field $405 \mathrm{~g} / \mathrm{m}^{2} \cdot \mathrm{y}$, which is $76 \mathrm{~g}$ more than the maximum green standing crop.

The method described by Wiegert and Evans (1964) is probably the most accurate adaptation of the harvesting method (cf. also TRACZYK 1968). The chief difficulty in their method lies in the reliable determination of the decomposition rate of detritus. According to their results, the actual production was 2.5-5.0 times larger than the peak green biomass due to extensive dying during the growing period. In contrast ODum et al. (1962) report that mortality in an abandoned field in Georgia was only few per cents of the maximum standing crop during the growing period. The shorter formula of WIEgERT and Evans (1964) gave $415 \mathrm{~g} / \mathrm{m}^{2}$ for annual net primary production of aboveground vegetation in the reserved field, which is in good accordance with the result obtained by the summing method. We consider that both figures are more likely to be underestimates than overestimates (cf. TRACzYK 1968, Table 7).

Yearly changes in the production of meadows may be striking (Table 6). JAKobsons (1972) noticed in 1967-69 in valley meadows in Southeastern Norway also great variations in annual production (e.g. $45-145 \mathrm{~g} / \mathrm{m}^{2}$ and $145-280 \mathrm{~g} / \mathrm{m}^{2}$ ). The growing period in 1973 was in the Jyväskylä district warmer and more rainy than on the average. In spring 1974 the amount of detritus was greater than in 1973, so that the production in 1972 had obviously been lower than in 1973. One should, however, take into account the accumulation of detritus in old fields (TraczYK 1968, HokkAnen 1976).

The measurement of the underground production is much more difficult than that of the aboveground parts. No useful method for determining the mortality of roots has been described. The sorting of root samples according to species is mostly too laborious in ecological works. Frequently the root production is estimated by subtracting the minimum biomass from the maximum. This is an underestimate, because mortality and the consumption of animals are disregarded. In grassland ecosystems the ratio of aboveground production to underground production varies greatly (Table 6) (BRAY 1963).

The total annual net primary production (above- plus underground parts) amounted in the reserved field to $750 \mathrm{~g} / \mathrm{m}^{2}$, which converted to energy units, equals one per cent of the radiation energy usable for photosynthesis. According to Golley (1960), roughly 50 per cent of the total radiation energy is suitable for assimilation. The energy assimilated by the plants was in fact greater, because about $25 \%$ of the gross production is lost through respiration (Golley 1960). In an abandoned field in Michigan the net utilization percent was 1.1 (Golley 1960).

The plant taxa were divided in this work into five groups on the basis of curves describing seasonal variations in their green biomasses. The members of the two first groups (e.g. Achillea ptarmica and Ranunculus repens) had clear maxima in mid-summer followed by rapid withering and shedding. Their production could be estimated quite reliably, because the production after the biomass peak was obviously negligible. The species in the third group had 
a long biomass maximum, which possibly included a minimum in JulyAugust (Deschampsia caespitosa, Poa pratensis, and Agrostis spp.) Although TRACZYK (1968) states that most vascular plants in his study area had a clearly unimodal biomass curve, in 1964, when July was rather dry, e.g. Deschampsia had a weak minimum in July and August. The use of maximum green standing crop as an estimate for net primary production leads in these species to clear underestimation because the dying of vegetation conceals production during a long period. More accurate results would have been obtained by using the maximum value of the rooted biomass (green plus dead) as was done by Gyllenberg (1969). The species in the fourth group had a late maximum after a relatively even growth and the method used was obviously quite valid because dying during summer was obviously on a small scale.

RAPPE (1963) has noticed in many graminids an internal growth rhythm, which is relatively weakly affected by external factors. Many graminids have, according to him, two growth maxima during the year. The biomass curves of Poa pratensis, Agrostis spp., and Deschampsia caespitosa point to the same conclusion. Festuca rubra has, according to Rappe, a long even growth period conflicting with the previous species. In the reserved field the green biomass of Festuca remained high for a long time end even increased in the late humid summer after a dry period.

\subsection{Animals}

The arthropods of the field stratum were sampled nine times by a suction apparatus. Corresponding studies on the fauna of grasslands have been made e.g. on a farm in Hälsingland in Sweden (JüRISOo 1964) and in the Vistula Valley in Poland. Jürisoo used the netting method and so was not able to estimate the actual densities.

Leafhoppers were the most numerous insects of the field stratum and the most abundant species were Arthaldeus pascuellus, Elymana sulphurella, Streptanus sordidus, Agallia brachyptera, Muellerianella brevipennis, Aphrodes flavostriatus, and Diplocolenus abdominalis. In a natural meadow in the Vistula Valley the dominating leafhoppers were Macrosteles leavis (Rib.), Delphacodes venosus and Arthaldeus pascuellus and the number of species common to both areas was eight. The peak density of the reserved field $\left(329 / \mathrm{m}^{2}\right)$ exceeded clearly that of the natural meadow in the Vistula Valley $\left(42.5 / \mathrm{m}^{2}\right)$.

\subsection{Aspects and the ecosystem}

The vegetation of the reserved field was divided on the basis of SørEnsen's and Renkonen's indices into three seasonal aspects: 1) Autumn, winter and spring aspect, 2) Early summer aspect, 3) Mid- and late summer aspect. The same aspects were distinguished also visually from slides taken on each sampling day. They were named according to the visually dominating vegetation components: 1) Detritus aspect, 2) Ranunculus and 3) Achillea ptarmica Poaceae aspect.

The leafhopper aspects coincided well with those of the vegetation. They differed from the three seasonal communities of oat fields (RAATIKAINEN 
1971). In addition to the largely different species composition, particularly the timing of the aspects is affected by the fact that many species of the oat fields hibernate elsewhere, which causes a delay in their occurrence in the oat fields.

Owing to their relative simplicity grasslands are perhaps the most thoroughly studied terrestrial ecosystems. However, no study covering the energetics of the entire ecosystem has been made. Energy budgets of single species or food chains have been studied, however (e.g. Golley 1960, WIEGERT 1964, 1965, Gyllenberg 1969). Measurements required for an accurate estimation of secondary production were not taken in this study either (see GoLLEY 1968). However, some features of the structure and function of the aboveground subsystem could be revealed. The biomass of the vegetation and animals was highest on 21. VII. The standing crops of green vegetation field stratum, herbivores and carnivores were $328,1.0$ and $0.06 \mathrm{~g} / \mathrm{m}^{2}$. Soil or soil surface inhabiting mites and springtails are not included. The weights of animals are mostly taken from the results of studies in the Vistula Valley (KAJAK 1971, ANdrzejeWska 1971, Olechowicz 1971). The figures are only tentative, and, for example, the amount of carnivores may be overestimated, because some of them might prey outside the study area (shrews, pygmy weasel). The dynamics in amounts of total radiation (energy source), green biomass (primary producers), abundance of adult leafhoppers (example of the herbivores), and spiders (example of the carnivores) are given in Fig. 9. It should be noted

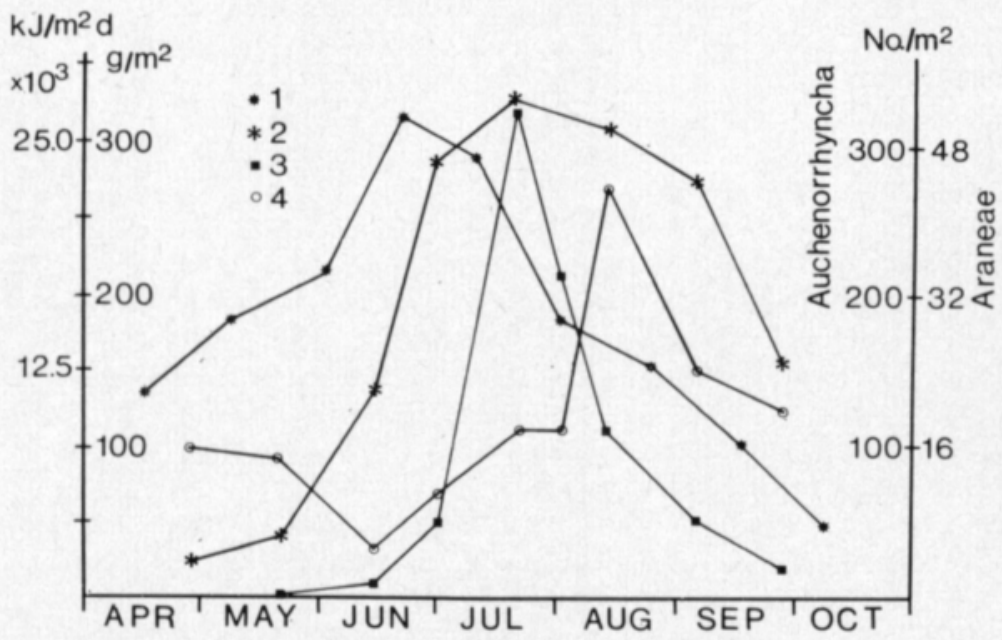

Fig. 9. Seasonal dynamics of total radiation energy (1), green biomass (2), adult leafhoppers (3), and spiders (4).

that the variables do not have the same units. It appears that the higher the trophic level the later it reaches the maximum. The curves indicate mainly the amounts of energy available to the next trophic level, but probably curves representing the actual production rates would have rather similar timings.

Acknowledgements. We are grateful to Mr. Heikki Hokkanen, M. Sc., who took part in the field and laboratory work. The financial support from the National Research Council for Sciences is greatly appreciated. 


\section{REFERENCES}

Andrzejewska, L. 1971. Production and population density of leafhopper communities. Ekol. Pol. 19: 151-172

Andrzejewski, R. \& Jezierski, W. 1966. Studies on the European hare. XI. Estimation of population density and attempt to plan the yearly take of hares. Acta Theriol. 11: $433-448$.

BrAY, J. K. 1963. Root production and the estimation of net productivity. Can. J. Bot. 41: $65-72$.

Cummins, K. W. \& Wyuchecк, J. C. 1971. Caloric equivalents for investigations in ecological energetics. Mitt. Int. Ver. Limnol. 18: 1-158.

Ehrendorfer, F. 1973. Liste der Gefässpflanzen Mitteleuropas. 318 p. Stuttgart.

Golley, F. B. 1960. Energy dynamics of a food chain of an old field community. Ecol. Monogr. 30: $187-206$

- - 1965. Structure and function of an old field broomsedge community. Ecol. Monogr. 35: $113-131$.

- -1968 . Secondary productivity in terrestrial communities. Amer. Zoologist 8: 53-59.

Gyllenberg, G. 1969. The energy flow a Chorthippus parallellus (Zett.) (Orthoptera) population on a meadow in Tvärminne, Finland. Acta Zool. Fenn. 123: 1-74.

Heikinheimo, O. \& RaAtikainen, M. 1962. Comparison of suction and netting methods in population investigations concerning the fauna of grass leys and cereal fields, particularly in those concerning the leafhopper Calligypona pellucida (F.). Publ. Finn. State Agric. Res. Board 191: 1-31.

Hokkanen, H. 1976. Pakettipeltojen tuotoksesta ja eliöyhteisöistä Keski-Suomessa. Manuscr. 51 p. (Available at Dept. Biology, University Jyväskylă, Finland).

Huhta, V. \& RaAtikainen, M. 1974. Spider communities of leys and winter cereal fields in Finland. Ann. Zool. Fenn. 11: 97-104.

JAAtinen, S. \& KärкKärnen, U. 1970. Pellonvaraustoiminta Suomessa 1969 ja sen tulokset. Summary: The reserving of fields in Finland in 1969 and its results. Asutustoiminnan Aikakauskirja 23, 1: 5-12, 28.

_- — \& KäRKKÄrnen, U. 1971. Vuoden 1969 pellonvaraustoiminta. Summary: The fieldreservation programme of Finland in 1969. Helsingin Yliopiston Maantieteen Laitoksen Julkaisuja B $7: 1-42$.

— _ \& NYGÅRD, M. 1972. Vuosien 1970-71 pellonvaraustoimınta ja vuoden 1970 steurastuspalkkiolakis. Summary: The field-reservation programme and the slaughter-subsidy Act in Finland 1970-1971. Helsingin Yliopiston Maantieteen Laitoksen Julkaisuja B 12: $1-63$.

— - \& NYGÁRD, M. 1973. Pellonvaraustoiminta Suomessa paikallisella tasolla. Summary: Field-reservation activity in Finland on a local level. Terra 85: 149-162.

Jakobsons, P. 1972. Struktur und Produktion alter Dauerwiesen in einem Talgebiet in SüdOst Norwegen. Meld. Norges Landbr.-högsk. 51: 1-23.

Jürisoo, V. 1964. Agro-ecological studies on leafhoppers (Auchenorrhyncha, Homoptera) and bugs (Heteroptera) at Ekensgård farm in the province of Hälsingland, Sweden. Stat, Växtskyddsanst. Medd. 13, 101: 1-147.

KАјАк, A. 1971. Production and consumption of field layer spiders. Ekol. Pol. 19: 197-211.

Kosonen, M. 1969. Production, composition and seasonal growth rhythm of some dry meadow communities on the South coast of Finland. Comment. Biol. 31: 1-23.

LinkolA, K. \& TirikкA, A. 1936. Uber Wurzelsysteme und Wurzelausbreitung der Wiesenpflanzen auf verschiedenen Wiesenstandorten. Ann. Bot. Soc. „Vanamo» 6:1-207.

MILNER, C. \& Hughes, R. 1968. Methods for the measurement of the primary production of grassland. IBP Handbook 6: 1-70.

Odum, E. P., Connell, C. E. \& Davenport, L. B. 1962. Population energy flow of three primary consumer components of old-field ecosystems. Ecology 43: 88-96.

Olechowicz, E. 1971. The number of emerged Diptera and their elimination. Ekol. Pol. 19: $183-195$.

RaAtikainen, M. 1971. Seasonal aspects of leafhopper (Hom., Auchenorrhyncha) fauna in oats. Ann. Agric. Fenn. 10:1-8. 
- - \& Rantikainex, T. 1975. Heinänurmien sato, kasvilajikoostumus ja sen muutokset. Summary: Yield, composition and dynamics of flora in grasslands for hay in Finland. Ann. Agric. Fenn. 14:57-191.

RAPPE, G. 1963. A yearly rhythm in production capacity of gramineous plants. A I Experiments in plots in the field. Oikos 14: 44-58.

RENKonen, O. 1938. Statistisch-ökologische Untersuchungen über die terrestrische Käferwelt der finnischen Bruchmoore. Ann. Zool. Soc. 'Vanamo' 6:1-231.

Sorensen, T. 1948. A method of establishing groups of equal amplitude in plant sociology based on similarity of species content. K. Danske Vidensk. Selsk. Biol. Skr. 5,4:1-43.

TrAczYK, T. 1968. Studies on primary production in a meadow community. Ekol. Pol. 16: 59-100.

- - 1971. Geobotanical description and primary production. Ekol. Pol. 19: 93-106.

Wiegert, R. G. 1964. Population energetics of meadow spittlebugs (Philacnus spumarius L.) as affected by immigration and habitat. Ecol. Monogr. 34: 217-241.

- - 1965. Energy dynamics of the grasshopper populations in an old field and alfalfa ecosystems. Oikos 16: 161-176.

- $-\&$ Evans, F. C. 1964. Primary production and the disappearance of dead material on an old field in southeastern Michigan. Ecology 45: 49-63.

\title{
SELOSTUS
}

\section{Pakettipellon primaarituotos ja kenttäkerroksen eliöstön vuodenaikaisrytmiikka}

\author{
Timo TÖrmäLÄ ja Mikko RaAtikainen \\ Jyväskylän Yliopisto, Biologian laitos
}

Tutkimus kohdistui Jyväskylän maalaiskunnassa sijaitsevaan neljä vuotta paketoituna olleeseen peltoon. Maanpäällisistä ja -alaisista kasvinosista otettiin näytteet kahdeksan kertaa kasvukauden aikana. Kasvillisuus leikattiin kunakin näytteenottokertana kahdeltakymmeneltä $0.25 \mathrm{~m}^{2}: \mathrm{n}$ alalta, ja juuristosta otettiin näytteet samoista kohdin lieriölapiolla.

Juuriston biomassa oli koko kasvukauden ajan suurempi kuin maanpäällisen vihreän (elävän) kasvillisuuden, ja sen maksimi ( $770 \mathrm{~g} / \mathrm{m}^{2}$ kuivapainona) oli syyskuun alussa. Kariketta oli keskimäärin $300 \mathrm{~g} / \mathrm{m}^{2}$, ja se oli minimissään kesä-heinäkuussa ja maksimissaan kasvillisuuden lakastuttua myöhäissyksyllä. Vihreän kasvillisuuden biomassan maksimi oli heinäkuun lopussa $\left(328 \mathrm{~g} / \mathrm{m}^{2}\right)$. Maanpäăllisten kasvinosien tuotokseksi saatiin $405-415 \mathrm{~g} / \mathrm{m}^{2}$ laskutavasta riippuen ja juuriston tuotos oli $343 \mathrm{~g} / \mathrm{m}^{2}$. Yhteenlaskettu tuotos oli noin $750 \mathrm{~g} / \mathrm{m}^{2}$ vuodessa, ja se vastasi energiasisällöltään noin $0.5 \%$ :a kasvukauden aikana pellolle tulleesta auringon säteilyenergiasta.

Vihreän biomassan kausivaihtelu ja maksimi saatiin selville 56:Ita lajilta tai lajiryhmältä. Runsaimmat lajit jaettiin viiteen ryhmään maksimin ajoittumisen ja keston perusteella.

Niveljalkaisista otettiin näytteet moottori-imurilla kasvien leikkuualojen vierestä. Useimpien eläinryhmien yksilömäärissä oli selviä vuodenaikaisvaihteluita. Kenttäkerroksen tärkein hyönteisryhmä oli kaskaat, joita oli keskimäärin $61.4 \mathrm{yks} . / \mathrm{m}^{2}$ heinäkuun loppuun sijoittuneen maksimin ollessa 329 yks./m². Kaskaslajit jaettiin kolmeen ryhmään niiden runsaimman esiintymisen ajankohdan perusteella, ja kaskasfauna jaettiin vastaavasti kolmeen kausiyhteisöön.

Pikkunisäkkäiden esiintymistä tutkittiin elävänä pyytävillä loukuilla. Runsain laji oli metsäpäästäinen, ja harvinaisena pidettyä korpipäästäistäkin saatiin kolme yksilöä. Peltomyyräkanta oli hyvin niukka.

Kasvissyöjien biomassa oli maksimissaan heinäkuun lopulla, ja se oli tällöin noin $0.3 \%$ vihreän biomassan määrästä. 